\title{
Britain forms panel to study barriers to women scientists
}

London. The British government has asked a group of women scientists to study what can be done to lower the barriers faced by women in science and technology.

The working party will be chaired by Nancy Lane, lecturer in cell biology at the University of Cambridge, who has already been advising the prime minister, John Major, on the government's proposed Citizen's Charter. It will make its proposals to a new Cabinet Office Committee on Women in Science and Technology chaired by William Stewart, the government's chief scientific adviser.

In announcing the government's decision to set up the new committee, William Waldegrave, the cabinet minister responsible for science and technology, acknowledged last week that women scientists face more daunting career prospects than their male counterparts - if they do not drop out altogether. "It is obvious that we are not using the resources of half of our people properly", Waldegrave said.

So far, however, the government appears reluctant to push for aggressive measures to change this situation. Waldegrave said he opposes quotas for fear of "ghettoizing" women in science and prefers an approach taken by the medical profession that has encouraged more women to become doctors primarily by changing its image.

Although the situation is improving, the prospects for women remain relatively bleak. At the undergraduate level, for example, women are well represented in biology but poorly in other areas - particularly mathematics, physics and engineering - where they make up only one-third of undergraduates.

In addition, the problem gets worse as their careers progress. In the Civil Service, for example, women make up 35 per cent of those at the assistant scientific officer grade but only 20 per cent of higher scientific officers and 9 per cent of senior scientific officers. There are thought to be only two female professors of physics and one of chemistry in British universities.

Arguing that equal-opportunity legislation is not enough, women members of various professional organizations have sought programmes that recognize, for ex-

\section{IMAGE UNAVAILABLE FOR COPYRIGHT REASONS}

\section{Waldegrave, Stewart and Lane}

ample, the importance of adequate childcare facilities. The Agricultural and Food Research Council, for example, has adopted measures ranging from special courses designed to equip women for senior positions to an agreement to increase the numbers of women in senior grades by at least 5 per cent a year over the next five years.

Other institutions, however, have been less responsive. "One problem is that men may not entirely understand the barriers that women scientists face," says Lane.

The working party will hold a one-day public meeting at the Royal Society in London at the end of May. Its report is due to be published in the autumn, and a reference to its work is likely to be made in the forthcoming White Paper on the organization of science.

David Dickson

\section{Woman at NIH trail men in salaries and tenure}

Bethesda, Maryland. Women scientists working at the US National Institutes of Health $(\mathrm{NIH})$ are granted tenure less frequently and earn less than their male colleagues, according to a new report by a task force looking at gender issues on the NIH campus. Although women make up about 30 per cent of the NIH fellows in the past decade, they represent only 18 per cent of newly tenured researchers during that time.

\section{A tenuous hold on tenure at NIH}
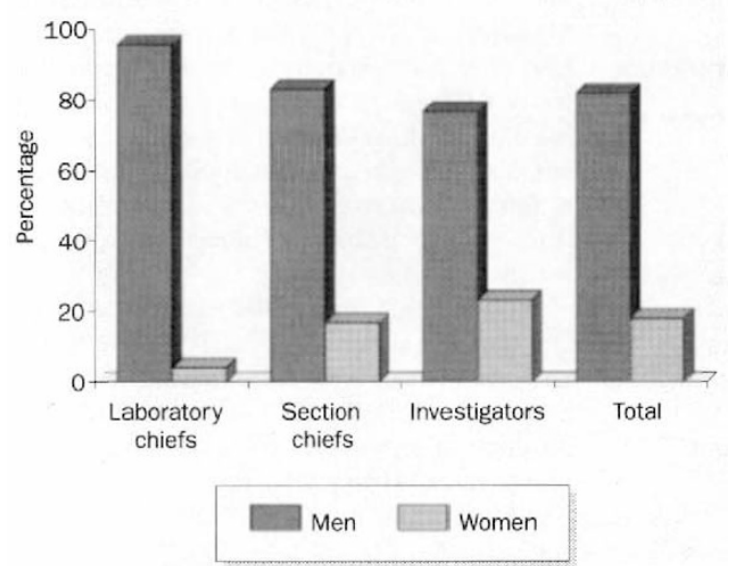

In addition, a preliminary analysis shows that men earn between $\$ 1,000$ and $\$ 6,000$ more in basic pay than women of the same rank.

The disparities are the result of a lack of uniform policies for tenure, promotion and pay scale at NIH, according to a task force set up in 1991 by the NIH director, Bernadine Healy, and reorganized this past summer. It is difficult for junior researchers to know how best to advance their careers because the scientific directors of NIH's 15 institutes and centres exercise considerable control over that information, which often is not available in print. Hynda Kleinman, chair of the task force and a developmental biologist at the National Institute for Dental Research, says the fact that so many senior women scientists have husbands who work at NIH is evidence not of nepotism but of the difficulty of obtaining the necessary career information through normal channels.

Only about 5 per cent of NIH fellows obtain tenured positions, but the chances for women are made worse by their low visibility and the attitudes of their male peers. Name recognition is an important factor in tenure decisions, says Kleinman, but women are invited to outside meetings less often than their talents merit because of an informal 'old boys' network'.

$\mathrm{NIH}$ officials have in general responded positively to the recommendations made by the task force and by other recent internal reviews. Lance Liotta, deputy NIH director for intramural research, says that comments will be sought on a draft procedure for awarding tenure to appear in the next issue of a newsletter begun recently by NIH to improve internal communications. Last year, almost half of those receiving tenure were women, an improvement that Kleinman attributes to the greater emphasis placed on the issue by Healy and to the abundance of eligible women who were denied tenure in previous years.

A council of women scientist advisers elected from each institute has been formed to discuss these issues and to improve communication between laboratory chiefs and women scientists as well as among women at NIH. One adviser has asked for job descriptions from each woman in her institute to encourage their participation on panels and at meetings. There are also plans for a new lecture series named for a woman that will feature women scientists at NIH.

Jenna Roberts 